\title{
肝臓障碍時に於ける腸管吸収機能に就いて
}

附. アゾルビン $\mathrm{S}$ 経口投与による肝臟機能検查法の可能性の検討

$$
\begin{aligned}
& \text { 日本医科大学薬理学教室（主任 西村菊次郎教授） } \\
& \text { 太田宏 }
\end{aligned}
$$

\section{Hiroshi Oota}

\section{I. 緒言}

正常時及び肝㯺異常時の腸管の色素㽖叹に関しては Haidenhein 以降多数の研究発表がある。肝藏疾患時 儿於ては，消化液分泌不全飞基く消化力低下及び間脉， 系を主とする循環不全等により腸管吸収機能湾化を 来し得べき事は容易に理解し得る。そこで肝䑏機能に 障㥂のある場合，腸管の吸収機能が如何な程度流暗， を受けるものであるかを知るうとして，アゾルビンS （以下 Az. S と略す）を経口的飞投与して肝臓障碍 時汸於ける腸管吸収の模様を追究した。これは朋臓疾 患㭧者の栄養及び治療炕些かでる貢献せんとするるの である。占，それと共に本研究の今一つの目的はAz.s に依る肝臓機能查法が該色素の静脉注射によるもので あるから，これを経口的江投与しても肝臟機能検查が 可能か不かを検するにある。

肝臓障碍之腸管吸収機能との関係については浜中 ${ }^{11}$ は neutral-rot, Phenolsulphonphthalein を, 加藤 は Phenol-rot を用いて，更飞触谷 就いて実験を行い，何れる肝臟障碍時に於ては晹管吸 收機能が減弱している事を報告して居る。

私は Az. S を経口投与し，その尿中排泄量を測定 し，腸管よりの吸収状態を推測した。既火知られて居 る如く，Az. S が血中に吸収されるとその大部分は短 時間で胆汁内に排泄され，尿中には僅かしか排泄され ないが、肝茞汇排泄障碍が存在する時には血中に入つ

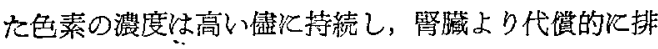
泄されるが，すともと等臟尗り排泄され難いので単位 時間内の排泄量の限界飞達する迄は同一時間内の排泄 量が堌加するが，その後訬排泄時間の延長を来してく ると云われている。

即ち，若し肝臓障害時飞於て Az. S の腸管よりの 吸収が正常時の吸収量飞比べて大量若しくは等量の時 は勿論, 少量でもとの程度の甚しくない時は当然尿中 $\mathrm{Az} . \mathrm{S}$ 排泄量は正常の場合より增加して来る事とな る。故江 Az. S を経口投与して，その尿中排泄量か らは腸管の吸收状態を正確沈判断し難いと考方泉え
るが，若しそれが可能であれば臨床上甚だ便利である ので, 果して可能であるか否かを検する目的で生体実 験と共保生晹管灌流尖験を行い，その成績を比較， 考察した。

\section{II. 実験方法}

A. 尿中 Az. S 定量法

Az. S の定量法は従来コンパラトール, Bürker 氏 比色計等を用いる方法があるが，何れる肉腿的に行う るので，主観に上る誤差が多分に考光られ，更に尿色 の濃い場合，黄䏣尿等の場合には正確を期し難い。

そこで私は燐タングステン酸を用いて尿色素の脱色 を行い，光電比色計沙よる尿中 Az. S の微量定量法 を考案し，実験汇使用した。

a) Az. s の物理的, 化学的性筫飞関する央験

i) 温度による影響

Az. S $1 \%$ 浴液を泠蔵庫内 (約 $5.0^{\circ} \mathrm{C}$ ) 飞 1 及び 24 時間鯮蔵して，その前後の濃度を測定したが変化な く, 又, 硫酸酸性溶液を沸滕温浴 1 時間して, その前 後の濃度を測定したが変化はない。

ii）透過率と $\mathrm{pH}$ との関係( (第 1 表)

Az. S $1 \%$ 溶液 $5 \mathrm{cc}$ をアルカリ性にする時は Az. $\mathrm{S}$ は色調を変克鮮赤色を呈し，第 1 表の如く透過率は 増加（即ち，見掛け上濃度の減少）するが，是れに濃 硫酸 2 滴を滴加して酸性污すると,アルカリ滴加以前 の標準の瀑度を示す。(この事はアルカリ尿の定量に 際しては重要な事である。即ち,アルカリ尿に Az. S を添加して，硫酸酸性にして定量しても，Az. S 量に 注全く影響を認めない) 又, Az, S 溶液に初めから濃 硫酸 2 滴を滴加して字影響は認められない。

iii）透過率と試薬放置時間との関係

Az. S $19 \%$ 溶液及び硫酸酸性溶液を室温江放置し， 以後1.2.3.4及び 24 時間後に透過率を測定したが変化 は認められない。及，3週間放置して子変色しない。

b) 定量法

i）至適波長の決定

Az. S の吸收極大について Conn") は, 約 $525 \mathrm{~m} \mu$ 
と述へているが，私は Az. S 20 r $/ \mathrm{ccc}$ 溶液を検体とし て分光光度計により至適波長を測定し，500 $\mathrm{m} \mu$ 《财 収極大を示す事を知つた。(第1図)

ii) 试薬

$$
\begin{aligned}
& \text { イ，濃硫酸 } \\
& \text { 口，10\%燐タングステン酸水溶滩 }
\end{aligned}
$$

iii）実施方法

\begin{tabular}{|c|c|c|}
\hline 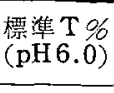 & 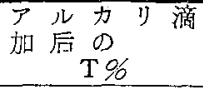 & 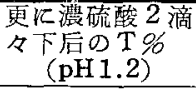 \\
\hline 18.0 & $* 25.8$ & 18.5 \\
\hline 38.1 & 44.5 & 39.0 \\
\hline 42.5 & 49.5 & 41.2 \\
\hline 53.0 & 60.2 & 53.0 \\
\hline 57.0 & 64.0 & 56.2 \\
\hline 60.0 & 65.8 & 58.5 \\
\hline 13.5 & $* * 20.0$ & 13.5 \\
\hline 14.0 & 20.0 & 14.0 \\
\hline 27.2 & 34.0 & 27.2 \\
\hline 36.0 & 42.5 & 36.5 \\
\hline 40.5 & 46.5 & 39.2 \\
\hline 45.0 & 52.0 & 44.5 \\
\hline
\end{tabular}

第 1 表 透過率と $\mathrm{pH}$ との関係

$10 \% \mathrm{Na}_{2} \mathrm{CO}_{3} 2$ 滴々下后のT\%(pH 9.0)

** $10 \% \mathrm{NaOH} 2$ 滴々下後のT\%（pH 11.4)

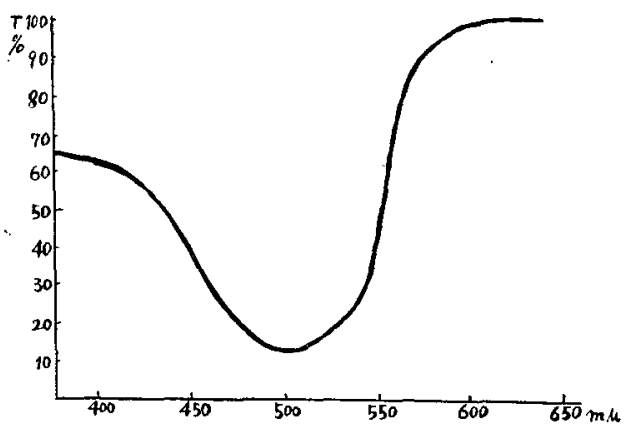

第 1 図 Absorption Spectrum of Azorubin $\mathrm{S}$

被検尿 $(5 \mathrm{cc})$ に濃硫酸 2 滴を加光て酸性となし, 是 れに等量の $10 \%$ 燐タンダステン酸試薬を加え， 3000 回転，10分間遠心沈澱する。この上清液老光電比色計

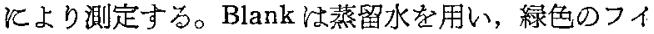
ルター（波長带500 570 m $\mu$ ) 党使用した。遠沈後可 及的速か測定するのがよい。これは時間の経過とと

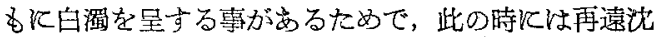
後測定すればよい。 iv) 微量定量淔線

次の如く Az. S $1 \mathrm{mg} / \mathrm{dl} \sim 4 \mathrm{mg} / \mathrm{dl}$ 溶液の定量直線 を得る。(第 2 図，第 2 表）

V) 测定愦差

誤差の範囲怡絶対值で+9〜ー7\%で，透過率を比較 するとさ 1.5 目盛以内である。(第 3 表)

誤差について考えると，光電比色計艺のものの読み の誤差は，透過率で士 $1 / 2$ 目盛卢であり，即ち，士 $1 / 2$ 目 盛の誤差が絶対值に加かるために被検量の絶対值が小 さくなればなる程，誤差が大きくなる事は十分考えら れる事で, 斎藤ら)光霄比色計そのるのの測定誤差 第 2 表 定 量実测值

\begin{tabular}{|c|c|c|}
\hline $\mathrm{mg} / \mathrm{dl}$ & $\mathrm{T} \%$ & $-\log \mathrm{T}$ \\
\hline \multirow{3}{*}{1} & 81.0 & 0.092 \\
& 81.5 & 0.089 \\
\hline & 81.5 & 0.089 \\
\hline 2 & 65.0 & 0.187 \\
& 65.5 & 0.184 \\
\hline 3 & 66.0 & 0.181 \\
& 53.0 & 0.276 \\
\hline & 53.5 & 0.272 \\
& 53.0 & 0.276 \\
\hline & 43.5 & 0.362 \\
\hline & 43.0 & 0.367 \\
\hline
\end{tabular}

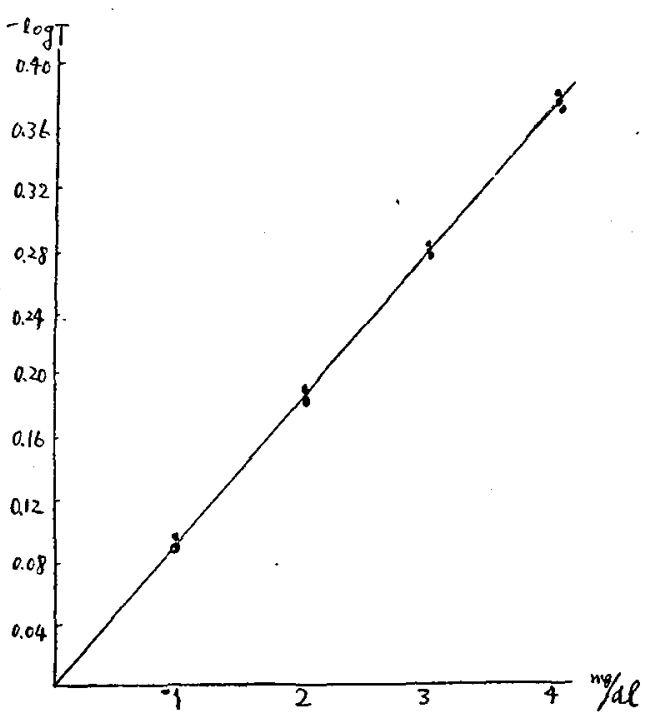

第 2 図·Azorubin $\mathrm{S}$ 微量定量直線 
第 3 表 剆 定 詔 差

\begin{tabular}{|c|c|c|c|c|c|}
\hline & \multicolumn{2}{|c|}{ 透過率 ( T \%) } & \multicolumn{3}{|c|}{$\mathrm{mg} / \mathrm{dl}$} \\
\hline & 対照值 & 実测值 & 対照继 & 实湘值 & 実測值 $\times 100$ \\
\hline 1 & 94.0 & 93.5 & 0.2875 & 0.3125 & 108.7 \\
\hline 2 & 92.0 & 92.0 & 0.3875 & 0.3875 & 100.0 \\
\hline 3 & 91.0 & 90.5 & 0.4375 & 0.4631 & 105.9 \\
\hline 4 & 87.5 & 87.5 & 0.6256 & 0.6256 & 100.0 \\
\hline 5 & 87.5 & 87.0 & 0.6256 & 0.6625 & 105.9 \\
\hline 6 & 86.5 & 86.5 & 0.6875 & 0.6875 & 100.0 \\
\hline 7 & 84.5 & 84.0 & 0.80 & 0.825 & 103.1 \\
\hline 8 & 84.0 & 84.0 & 0.825 & 0.825 & 100.0 \\
\hline 9 & 84.0 & 85.0 & 0.825 & 0.775 & 93.9 \\
\hline 10 & 82.5 & 82.5 & 0.9125 & 0.9125 & 100.0 \\
\hline 11 & 82.0 & 82.5 & 0.9375 & 0.9125 & 97.3 \\
\hline 12 & 81.5 & 82.0 & 0.975 & 0.9375 & 96.1 \\
\hline 13 & 81.5 & 81.5 & 0.975 & 0.975 & 100.0 \\
\hline 14 & 81.0 & 81.5 & 1.0 & 0.975 & 97.5 \\
\hline 15 & 81.0 & 81.0 & 1.0 & 1.0 & 100.0 \\
\hline 16 & 78.5 & 78.5 & 1.15 & 1.15 & 100.0 \\
\hline 17 & 77.0 & 78.0 & 1.25 & 1.1875 & 95.0 \\
\hline 18 & 76.5 & 76.5 & 1.275 & 1.275 & 100.0 \\
\hline 19 & 76.5 & 77.0 & 1.275 & 1.25 & 98.0 \\
\hline 20 & 75.5 & 76.5 & 1.3375 & 1.275 & 95.3 \\
\hline 21 & 75.0 & 76.5 & 1.3625 & 1.275 & 93.6 \\
\hline 22 & 74.0 & 74.0 & 1.425 & 1.425 & 100.0 \\
\hline 23 & 72.0 & 71.0 & 1.5625 & 1.6375 & 104.8 \\
\hline 24 & 71.5 & 72.2 & 1.6 & 1.55 & 96.8 \\
\hline 25 & 70.5 & 71.0 & 1.6625 & 1.631 & 98.1 \\
\hline
\end{tabular}

註：対照値：Az.S を蒸留水に溶解した際の值 実湘值：対照值と等量の Az. S を尿に溶解し た際の值

が透過率の数が多くなるにつれて，大きくなる事を述 ベて居り, $(90 \% \cdots \cdots . .25 \%, 80 \% \cdots \cdots .2 .80 \%)$, 以上よ. り此の程度の誤差は許容さるべきすの考えられる。

c) 定量法の吟味

i）燐タングステン酸亡Az.S の财光度との関係 Az.S 溶液に 10\%燐タングステン酸溶液等量を加え て, 光電比色計によりその吸光度の変化を測定したが 変化は認められない。

ii）辚タングステン酸と㽷色との関係

硫酸酸性尿に10％橉タングステン酸溶液等量を加克 た場合, その避沈上清液は水様透明となり, 光電比色 計にても，蒸留水を対照として，その差は透過率で二 1.5 目盛である。(第 4 表)

即ち, この 1.5 目盛（正確には土 $1 / 2$ 目盛は光電比 色計自身の誤差）の誤差が絶対值に加わるために，被
検量が小となればなる程䛊苃が大きくなる事は前述し た通りである。

\section{B. 実験動物及び肝臓障㖊法}

実験動物何れも $2 \mathrm{~kg}$ 前後の白色雄性家鬼を用い， 四塩化炭素 (以下 $\mathrm{CCl}_{4}$ と記す) 及び総輸胆管結禁に 上り肝葴障碮を行つた。

第 4 表 舜タングステン酸と家色との関係

\begin{tabular}{|c|c|c|c|}
\hline \multicolumn{4}{|c|}{ 透過率 $\mathrm{T} \%$ (Blank は蒸留水) } \\
\hline 蒸 & & 水 & 攃タングステン酸処理尿 \\
\hline & 100.0 & & 98.5 \\
\hline & 100.0 & & 100.0 \\
\hline & 100.0 & & 98.5 \\
\hline & 100.0 & & 101.0 \\
\hline & 100.0 & & 98.5 \\
\hline
\end{tabular}

即ち, $\mathrm{CCl}_{4}$ 障碍例で社 $\mathrm{CCl}_{4}$ を $0.1 \mathrm{cc} / \mathrm{kg}$ 経㞋投与 又は右大腿皮下に注射した。総輸胆管結禁例では家躳 を背位に固定し，上腹部正中線に於て開腹し，総輸胆 管を露出し，腸管への開口部に近くこれを結禁した。

実験は $\mathrm{CCl}_{4}$ 障碍例では障碍後 24 時間, 総輸胆管結 紮例で結禁後 48 時間に行つた。向，経口投与実験 てでは実験前 24 時間は絶食させた。

C. 原採取法

ネラトンカテーテルにより，4時間に亘り 1 時間每 に採尿し，上記定量法に従つて Az. S を測定した。

尚, 正常例, 肝䁍障㧹例共, 実験前にズルフオサり チル酸法で尿中蛋白陰性なる事る確認した。

\section{III. 実験成 績}

A. 正常例 (第 5 表)

先つ実験敒最適当な経向投与量を決定するため K, 蒸留水 $15 \mathrm{cc}$ K Az. S 飞各々 $60,80,100 \mathrm{mg}$ 溶 解し，夫々ネラトンカテーテルにより経口投与し，4 時間総尿飞ついて前記定量法化より Az.S t测定し, 次の結果を得た。

$60 \mathrm{mg}$ 投与群では平均 $68.0 \mathrm{r}$ Kして, 投与量に対 乙，0.11\%，80 mg 投与群では平均 $235.6 r$ ，投与量に 対し $0.29 \%, 100 \mathrm{mg}$ 投与群では平均 $274.6 \gamma$, 投与量 に対し $0.27 \%$ Kして，80 mg 投与群と $100 \mathrm{mg}$ 投与群 の排泄率の間には推計学的には有意の差は認められな かつたが，しかし $80 \mathrm{mg}$ 投与群の方が排浛率が多少 多い傾向を有し，80 mg が経口投与量として最適と思 われう。60 $\mathrm{mg}$ と $80 \mathrm{mg}$ との閶の排泄量の格段の開 きは，60 mg 投与群では投与 Az. S 量の多くが組織

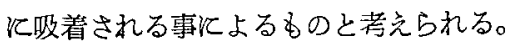


第 5 表（正常例）

アゾルビン $\mathrm{S}$ 経口投与量と尿中排泄量との関係

\begin{tabular}{|c|c|c|c|c|c|c|c|c|c|}
\hline \multirow{2}{*}{ 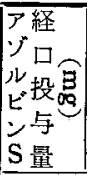 } & \multicolumn{2}{|r|}{ 兔 } & \multirow{2}{*}{\begin{tabular}{|l} 
尿時 \\
中 \\
初 \\
発間 \\
(分)
\end{tabular}} & \multicolumn{4}{|c|}{ アゾルビン $\mathrm{S}$ 尿中排泄量 $(\gamma)$} & \multirow{2}{*}{ 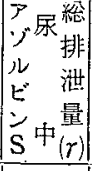 } & \multirow{2}{*}{$\begin{array}{c}\text { 排 } \\
\text { 泄 } \\
(\%) \\
\end{array}$} \\
\hline & 番号 & $\left|\begin{array}{l}\text { 体重 } \\
(\mathrm{kg})\end{array}\right|$ & & 1 時間 & 2 時間 & 3 時間 & 4 洔閏 & & \\
\hline \multirow{6}{*}{60} & 8 & 2.2 & 60 & 0 & 10.8 & 14.3 & 22.1 & 47.2 & 0.08 \\
\hline & 11 & 1.8 & 120 & 0 & 0 & 6.9 & 15.6 & 22.5 & 0.04 \\
\hline & 14 & 2.0 & 80 & 0 & 8.4 & 16.2 & 30.6 & 55.2 & 0.09 \\
\hline & 17 & 1.8 & 70 & 0 & 60.0 & 57.0 & 28.1 & 145.1 & 0.24 \\
\hline & 20 & 1.9 & 85 & 0 & 17.3 & 26.7 & 26.0 & 70.0 & 0.12 \\
\hline & \multicolumn{2}{|l|}{ 平 } & 均 & 0 & 19.3 & 24.2 & 24.5 & 68.0 & 0.11 \\
\hline \multirow{6}{*}{80} & 9 & 2.0 & 80 & 0 & 47.5 & 150.0 & 140.3 & 337.8 & 0.42 \\
\hline & 12 & 2.1 & 45 & 29.9 & 130.0 & 62.4 & 24.8 & 247.1 & 0.31 \\
\hline & 15 & 1.9 & 40 & 43.0 & 39.6 & 54.5 & 51.0 & 188.1 & 0.24 \\
\hline & 18 & 1.9 & 50 & 8.8 & 60.5 & 65.2 & 48.1 & $\mid 182.6$ & 0.23 \\
\hline & 21 & 1.8 & 40 & 66.0 & $5 \dot{9} .5$ & 59.7 & 37.1 & 222.3 & 0.28 \\
\hline & \multicolumn{2}{|l|}{ 平 } & 均 & 29.5 & 67.4 & 78.4 & 60.3 & 235.6 & 0.29 \\
\hline \multirow{6}{*}{100} & 10 & 2.0 & 65 & 0 & 63.8 & 108.5 & 102.2 & 274.5 & 0.27 \\
\hline & 13 & 2.0 & 40 & 34.5 & 102.0 & 113.6 & 108.0 & 358.1 & 0.36 \\
\hline & 16 & 1.9 & 60 & 0 & 68.9 & 84.1 & 76.0 & 229.0 & 0.23 \\
\hline & 19 & 2.0 & 40 & 7.7 & 82.8 & 97.5 & 26.3 & 214.3 & 0.21 \\
\hline & 22 & 1.9 & 40 & 3.4 & 140.8 & 79.8 & 73.2 & 297.2 & 0.30 \\
\hline & \multicolumn{2}{|l|}{ 平 } & 均 & 9.1 & 91.7 & 96.7 & 77.1 & 274.6 & 0.27 \\
\hline
\end{tabular}

3) 尿中初発時間は 1 時間 30 分 3 時間 30 分（8例中 6 例の 尿中初発時間は 1 時間 30 分 〜 1 時間 45 分の間にある)で, 正常例に比へ明 らか江荤延して居る。

4) 排泄終了は 25〜35 時間で，大多数は 25 ３0 時間に終了し正常例に比べて早い。

以上の如く，尿中排泄量の著明な減少，尿中 初発時間の幄延，正常例では 3 時間目が最も排 泄量多いのに反し，肝臟障碍例では 4 時間目が 最大で吸収の遅延が想像される事, 又, 排泄終 了時間が正常例に比へて促進している点等よ り, 肝臓障碍時には腸管吸収機能の減弱する事 が明らかに窥われた。

b) $\mathrm{CCl}_{4}$ 皮下注射例

$\mathrm{CCl}_{4}$ 経口投与例では，経口投与のために，腸 管代対する $\mathrm{CCl}_{4}$ の直接の影響が考克られ，此 の影響を除外するために $\mathrm{CCl}_{4}$ を皮下注射し肝 㖪障碍を行つた。 $\mathrm{CCl}_{4}$ 皮下注射例では $\mathrm{CCl}_{4}$ 経 口投与例比へ肝臓障碍の程度がより強いと一 般に云われている。

結果以

1) 4 時間総排 泄量は 平均 $93.9 r$ と著明に 減少し，正常例との間には 1960 危険率で有意 の差を㤎さ。

2) 4 時間目が最も多く

$80 \mathrm{mg}$ 経口投与群仿ては

1) 3 時間目が最方排浛量多く

2) 尿中初発時間忙 40 80 分

3) 排泄終了は 48 時間である。

以上を標準として次の如き実験を行つた。

以下 Az. S の経口投与量は一律に $80 \mathrm{mg}$ とし，ネ ラトンカテーテルを用いて Az. S $1 \%$ 溶液 $8 \mathrm{cc}$ を胃 内に注入し, 次いで蒸留水 $7 \mathrm{cc}$ をカデーテルを洗洛 する様にして追加注入した。

B. 肝臟障淂例 (第 6 表)

a) $\mathrm{CCl}_{4}$ 経口投与例

$\mathrm{CCl}_{4}$ を投与すれ音肝臓実䆩紐胞殊に肝小葉中心部に 種々の退行変珄を招来し，脂肪変性を来すと云われ， 肝臓毒として一般に使用されて居り，本報告の $\mathrm{CCl}_{4}$ 障碍例では教室の慣用に従い肝臓障碍24時間後に実験 を行つた。その結果は

1) 4 時間総排泄量は平均 $114.2 \tau$ と著明に減少し 正常例との間に忙 $1 \%$ の危険率で有意の差を認める。

2) 4 時間目が最子排泄量多く
3）尿中初発時間は 60 分〜1 時間 45 分と明らかに 幄㱏し，

4）排泄終了は 26〜48 時間で正常より早い傾向を 翏めた。

及, 以上より $\mathrm{CCl}_{4}$ 皮下注射例の方が経口投与例の 場合より腸管の吸収障碍が大である様に思われる。

\section{c) 総輸胆管結禁例}

総輸胆管を結紮すれば，24 時間後甈に 眼瞼結膜及 び眼球結膜等は軽度に黄色を呈し，黄䏣の発生を羿め 48時間後に至れば，其の程度著明となる。其病理組織 学的変化江就いては Simmonds, Bauer, Charcot, 䅴 田 ${ }^{6)}$ 等の研究があり, 胆汁整積による機械的作用, 並 びに胆管より漏出せる胆汁の化学的毒作用による結合 組織の增殖，肝臓実筫細胞の塆死等を来すと云う7。 結果忧

1） 4 時間総排泄量は平均 $79.7 \gamma$ にして, 正常例 との間には $1 \%$ 告険率で有意差を認も。

2） 4 時間目が排泄量最も多く

3）尿中初発時間は 50 分 2 時間 30 分と遅延し, 
$-54-(750)$

4) 排泄終了は何れ 48 時間以内で正常に比べ促 進している。

以上より，肝蔵障碍時に於ては腸管吸収機能の低下 を来すと云う事を略々推察する事が出来た。

C. Az. S 腸間膜静脉注入例（第 7 表）

上記方法に上る肝藏害碍時に於ける尿中 Az.S 排 泄量の減少が果して

i）腸管吸収機能の減弱によるものか，

ii）腸管吸収機能は正常で，即ち，血中には正常例 と略々等しい搌度に吸収されるが，敏葴乞の他藏器の 何らかの機能暴常によりて氺中排泄量が減少したので はないかと云う事が考光られる。此の場合，血中殊飞 門脉中の Az.S の濃度を测定する事が最望望しい と思われるが，Az.S の血中濃度を正確に測定する事 は難しいので，次の如く実験を行つた。即ら，正常 及び肝蔵障䅞家象に就いて，腸間膜静脉中に一定量の Az. S を注射して，その 4 時間の尿中排泄量を測定し た。即ち，も乙も腸管の吸収機能が相等しい場合，正 常家兔之肝臓障碍家鬼とでは尿中排泄量汇如何なる相 違を来すかを実験的に追究した。

尖験方法：

正常及び肝臓障碍家乘侙みK $196 \mathrm{Az} . \mathrm{S}$ 溶液 2.0 $\operatorname{cc}(20 \mathrm{mg})$ を腸閒膜静脉飞注射し， 4 時間に亘り，各 々 1 時間每に採尿し Az.S 学测定した。

肝藏障碍例は $\mathrm{CCl}_{4}$ を $0.1 \mathrm{cc} / \mathrm{kg}$ 皮下注射し，24 時 間後深験を行つた。

成緽は

1) 4 時間総排泄量仗, 正常例平均 $2418.7 r$ 肝臟 障碍例平均 $4881.0 \gamma$ Kして肝藏障碍例飞於ては, 正 常例との間に $5 \%$ \%の危険率で著明に尿中排泄量の増 加を認めた。

2) 何礼\&1時間目が排浛量最も多く

3）尿中初発時間恃正常例 13１5 分，肝㵶障碍例 5〜6 分にして, 訮藏障碍例の方が早い。

即ち, 肝藏障碍例と正常例の Az.S 吸収量が等乙 い場合には, 正常例に比して肝藏障碍例に於ては著明 K Az. S 㽷中排泄量の增加，尿中初発時間の促進を 来苯事となる。

以上の事実より考えて，肝䑏障碍時に於ては著明に 腸管吸収機能の減退を来す事が明らかとなつた。

D. 肝藏障碍後一定時日（7２1 日）経過後の晹管 败収機能について（第 8 表）

一般に肝臓は代償作用の強い藏器であり, 障碍され た肺㘕実質細胞も余程其の程度が強くない限りは时日
第 6 表 肝䑏障碍例

(アゾルビン S $80 \mathrm{mg}$ 経口投与)

\begin{tabular}{|c|c|c|c|c|c|c|c|c|}
\hline & \multicolumn{2}{|l|}{ 家 } & \multirow{2}{*}{$\begin{array}{l}\text { 尿時 } \\
\text { 中 } \\
\text { 初 } \\
\text { 発間 } \\
\text { (分) }\end{array}$} & \multicolumn{4}{|c|}{ アゾルビ S 尿中排泄量 $(r)$} & \multirow{2}{*}{ 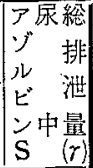 } \\
\hline & 番号 & $\begin{array}{l}\text { 体重 } \\
(\mathbf{k g})\end{array}$ & & 1 㭙間 & 2 時間 & 3 時間 & 4 時間 & \\
\hline \multirow{9}{*}{ 年 } & 23 & 2.2 & 150 & 0 & 0 & 8.8 & 17.5 & 26.3 \\
\hline & 24 & 2.0 & 105 & 0 & 22.0 & 27.6 & 32.0 & 81.6 \\
\hline & 25 & 2.0 & 95 & 0 & 7.2 & 45.6 & 126.0 & 178.8 \\
\hline & 26 & 2.2 & 90 & 0 & 114.8 & 55.2 & 42.0 & 212.0 \\
\hline & 27 & 2.1 & 100 & 0 & 3.0 & 21.9 & 55.0 & 79.9 \\
\hline & 28 & 2.0 & 100 & 0 & 24.0 & 41.0 & 39.0 & 104.0 \\
\hline & 29 & 2.0 & 90 & 0 & 55.0 & 14.4 & 151.9 & 221.3 \\
\hline & 30 & 2.3 & 210 & 0 & 0 & 0 & 9.6 & 9.6 \\
\hline & \multicolumn{2}{|l|}{ 平 } & 均 & 0 & 28.3 & 26.8 & 59.1 & 114.2 \\
\hline \multirow{6}{*}{$\begin{array}{l}\text { 四 } \\
\text { 塩 } \\
\text { 华 } \\
\text { 菜 } \\
\text { 皮 } \\
\text { 卢 } \\
\text { 注 } \\
\text { 射 } \\
\text { 例 }\end{array}$} & 31 & 2.1 & 100 & 0 & 20.2 & 30.6 & 48.6 & 99.4 \\
\hline & 32 & 2.0 & 85 & 0 & 19.6 & 24.2 & 42.0 & 85.8 \\
\hline & 33 & 1.9 & 60 & 0 & 28.3 & 54.4 & 73.6 & 156.3 \\
\hline & 34 & 2.1 & 105 & 0 & 6.3 & 17.9 & 16.0 & 40.2 \\
\hline & 35 & 2.1 & 90 & 0 & 20.0 & 30.0 & 37.8 & 87.8 \\
\hline & \multicolumn{2}{|l|}{ 平 } & 均 & 0 & 18.9 & 31.4 & 43.6 & $93: 9$ \\
\hline \multirow{6}{*}{$\begin{array}{l}\text { 総 } \\
\text { 輪 } \\
\text { 管 } \\
\text { 管 } \\
\text { 紫 } \\
\text { 例 }\end{array}$} & 51 & 1.9 & 50 & 28.0 & 48.0 & 43.5 & 67.5 & 187.0 \\
\hline & 52 & 2.2 & 150 & 0 & 0 & 5.0 & 20.0 & 25.0 \\
\hline & 53 & 2.0 & 100 & 0 & 7.0 & 12.0 & 14.3 & 33.3 \\
\hline & 54 & 2.1 & 95 & 0 & 18.2 & 28.0 & 34.2 & 801 \\
\hline & 55 & 2.1 & 110 & 0 & 6.5 & 20.4 & 45.8 & 72.7 \\
\hline & \multicolumn{2}{|l|}{ 平 } & 均 & 5.6 & 15.9 & 1.8 & 36.4 & 79.7 \\
\hline
\end{tabular}

第 7 表 アゾルビン $\mathrm{S}$ 腸間膜静脉注入例

\begin{tabular}{|c|c|c|c|c|c|c|c|c|}
\hline & \multirow{2}{*}{$\frac{\text { 家 }}{\text { 番号 }}$} & \multirow{2}{*}{$\frac{\text { 克 }}{\mid \begin{array}{l}\text { 体重 } \\
(\mathrm{kg})\end{array}}$} & \multirow{2}{*}{$\begin{array}{l}\text { 尿時 } \\
\text { 中 } \\
\text { 初 } \\
\text { 発間 } \\
\text { (分) }\end{array}$} & \multicolumn{4}{|c|}{ アゾルビ S 尿中排泄量 $(\tau)$} & \multirow{2}{*}{ 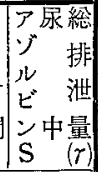 } \\
\hline & & & & 1 時間 & 2 時間 & 3 時間 & 4 時間 & \\
\hline \multirow{2}{*}{ 正 } & 36 & 2.2 & 13 & & 502.5 & 183.3 & 93.8 & 1863.6 \\
\hline & 37 & 1.9 & 15 & & 12 & 0.0 & 43.8 & 1.3 \\
\hline \multirow{2}{*}{ 常 } & 39 & 2.0 & 15 & 2040.0 & 137.5 & 55.0 & 38.8 & 3 \\
\hline & 平 & & 均 & 1646.3 & 617.5 & 96.1 & 58.8 & \\
\hline \multirow{4}{*}{$\begin{array}{l}\text { 肝 } \\
\text { 滥 } \\
\text { 障 } \\
\text { 碍 } \\
\text { 例 }\end{array}$} & 40 & 1.9 & 5 & 2012.5 & $\mid 1837.5$ & 975.0 & 106.3 & 493 \\
\hline & 41 & 2.0 & 5 & 4600.0 & 156.3 & 76.3 & 115.1 & 4947.7 \\
\hline & 42 & 2.2 & 6 & 2758.0 & 1456.3 & 367.5 & 182.5 & 476 \\
\hline & 平 & & 均 & 23 & 115 & 472.9 & 134.6 & \\
\hline
\end{tabular}

の経過と共に能く恢復, 再生する力を有する。又，か かる障碍肝蔵は時日の経過と共に漸次朋臓機能の恢復 
を来す事は既に知られている。

私怡此の場合，腸管吸収機能が肝歲機能の恢復飞良 い如何なる変化を来すかを追究する事により，肝藏機 能と腸管吸収機能との関係の幾分を知らうとした。

実験は, $\mathrm{CCl}_{4} 0.1 \mathrm{cc} / \mathrm{kg}$ 経口投与 24 時間後及び7〜 21 日後に同一家鬼につき, Az. S 経口投与央験を行 い,その尿中排泄量を测定した。

肝獩障碍後 24 時間では

1) Az. S 総排泄量壮 $103.7 \gamma$,

2) 4 時閒目が最も排泄量多く

3) 尿中初発時間は 1 時間 30 分 3 時間 30 分 ( 1 時間 30 分 1 時間 40 分が最多)

4) 排淮終了は 25〜35 時間である。

是に反し，肝臓障碍後 7〜21 日経過した例では

1) Az. S 総排泄電忙 $150.8 \gamma$ と増加し，

2) 4 時間目が最子排泄县多く

3）尿中初発時間は早くなり，45〜65分となる。但 し，排泄持続時間は変らない。

即ち，肝臓毒投与後，時日の経過之共飞 Az. S 排 浛量の增加を認めるようであるが，是れる推計学的に

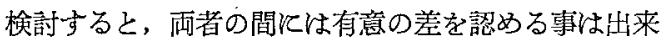
なからた。しかし，尿中初発時間の促進及び 3 時間目 排泄量吕増加乙て正常の排泄型に似て来ている点等を 考克合せると，腸管吸収機能も亦，旰藏機能の改善に 平行して幾分で当好転して来て居る事が推察出来た。

E. 肝臟障碍時飞於ける䀒臟機能九進剂の腸管吸収 機能に及洔す影響について（第 9 表）

第 8 表 肝葴障碍後二定時日経過後の腸管吸

収機能 (肝葴機能恢復と尿中排泄量との関係)

\begin{tabular}{|c|c|c|c|c|c|c|c|c|c|}
\hline & \multirow{2}{*}{$\mid$\begin{tabular}{|l|} 
家 \\
番号
\end{tabular}} & \multirow{2}{*}{$\frac{\text { 重 }}{\left(\begin{array}{l}\text { 体重 } \\
(\mathbf{k g})\end{array}\right.}$} & \multirow{2}{*}{\multicolumn{2}{|c|}{$\begin{array}{l}\text { 肝経 } \\
\text { 厡時 } \\
\text { 障過 } \\
\text { 中 } \\
\text { 碍日 } \\
\text { 初 } \\
\text { 発間 } \\
\text { (後) }\end{array}$}} & \multicolumn{4}{|c|}{$\begin{array}{l}\text { アゾルビ } \mathrm{S} \\
\text { 尿中排泄量 }(r)\end{array}$} & \multirow{2}{*}{ 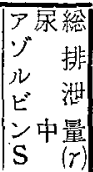 } \\
\hline & & & & & $\begin{array}{l}1 \text { 時 } \\
\text { 間 }\end{array}$ & 間 & $\begin{array}{c}3 \text { 時 } \\
\text { 間 }\end{array}$ & \begin{tabular}{|c|}
4 時 \\
間
\end{tabular} \mid & \\
\hline \multirow{5}{*}{$\begin{array}{l}\text { 㬴 } \\
\text { 臓24 } \\
\text { 障時 } \\
\text { 碍間 } \\
\text { 後 } \\
\text { 例 }\end{array}$} & 2 & & - & 100 & 0 & .0 & 21.9 & 55.0 & 79.9 \\
\hline & 28 & 2.0 & - & 100 & 0 & 24.0 & 41.0 & 39.0 & 104.0 \\
\hline & 29 & 2.0 & - & 90 & 0 & 5.0 & 14.4 & 51.9 & 221. \\
\hline & 30 & 2.3 & - & 210 & 0 & 0 & 0 & 9.6 & 9.6 \\
\hline & \multicolumn{2}{|c|}{ 平 } & \multicolumn{2}{|c|}{ 均 } & 0 & 5 & 19.3 & 63.9 & 100 \\
\hline \multirow{5}{*}{$\begin{array}{l}\text { 肝 } \\
\text { 臓二 } \\
\text { 障定 } \\
\text { 碍時 } \\
\text { 後旦 } \\
\text { 経 } \\
\text { 過 } \\
\text { 例 }\end{array}$} & 27 & 2.1 & 21 & 65 & 0 & 45.0 & 100.8 & 117.0 & 262.8 \\
\hline & 28 & 1.9 & 14 & 45 & 9.5 & 15.1 & 45.8 & 82.8 & 153.2 \\
\hline & 29 & 1.6 & 14 & 50 & 6.7 & 722.0 & 27.6 & 28.9 & 85.2 \\
\hline & 30 & 1.8 & 7 & 50 & 15.6 & 36.8 & 37.4 & 12.5 & 102.3 \\
\hline & \multicolumn{2}{|c|}{ 平 } & \multicolumn{2}{|c|}{ 均 } & 7. & $\theta$ & 52.9 & 60.3 & 150.8 \\
\hline
\end{tabular}

カルシウムが肝藏機能に対してて進的に作用する事

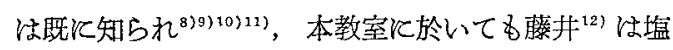
化カルシウムを目荷した家鬼に於いて，肝臟色素排泄 機能が著明飞穴進する事を報告して居る。

私以肝喴障碍家兔に於いて，斯る肝藏機能尣進剂が 腸管吸収機能に対して如何なる影響を及ぼすかる検索 した。即ち, 肝臟障碍時, 肝臟機能六進剂を使用した 場合，腸管吸取機能怔改善されるものであるろかと云 ろ事は臨木的にも興味ある問題である。

奏験方法: $\mathrm{CCl}_{4}$ を $0.1 \mathrm{cc} / \mathrm{kg}$ 皮下注射して肝藏を 障碍し，24時間後，10名塩化カルシウムを $1.0 \mathrm{cc} / \mathrm{kg}$ 静注し，垍化カルシウム静注 30 分後江 Az. S $80 \mathrm{mg}$ を経口投与し，4時間仁亘り各々1時閻铮に採㲾し， Az.S 測定した。結果は

1） 4 時間総排泄量恃平均 45.8 r飞て, 正常例 との間には 1900 危険率で有意の差を垫め $\mathrm{CCl}_{4}$ 皮下 注射例《比べても5\%の危険率で有意の減少を示し た。又, $\mathrm{CCl}_{4}$ 経口投与例及び総輸胆管結禁例に比べ ても著明に娍少している。塩化カルシウム投与後短時 間化して，かくの如き変化の行われる機序については 追求をしなかつた。

2) 3 時間目が最排泄量多く

3）尿中初発時間は 1 時間 40 分 2 時間で明らかに 幄延している。

、しかし，斯る㽷中 Az. S 排泄量の著明な減少は， 塩化カルシウム投与により，

i）肝㵴色素排泄機能のみが元進して，尿中排泄量 が娍少したのか，

ii）腸管吸収機能が元進しても，肝臟よりの色素排 泄機能が先進し，そのために尿中排泄量が減少したの か，不明である。

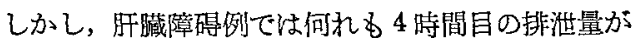
最子多いのに反して, 本例では 3 時間目が最も多く, 排泄の型が正常例飞似て居るのは興味澡く, 又 $\mathrm{CCl}_{4}$ 皮下注射による肝臓障碍例に比べてる著明に減少して いるのは注目すべき事である。

そこで私は斯る点を明らか沉するために，家象剔出 保生腸管灌流実験を行い，此の事実を追究した。

IV. 家克剔出保生腸管灌流実験（第 3 図）

剔出保生晹管灌流装置に就いてね今迄多数の報告が あり, 最近々於て子松井 ${ }^{132}$, 井田 ${ }^{14}$, 寺岡 ${ }^{15)}$ 等の実験 があるが，私は是等を多少改良して，次の如く害験を゙ 行つた。

\section{A. 実験方法}


$-56-(752)$

第 9 表 肝䑏障碍後塩化カルシウム負荷例

$\left(\mathrm{CCl}_{4} 0.1 \mathrm{cc} / \mathrm{kg}\right.$ 皮下注射 24 時間後

$10 \% . \mathrm{CaCl}_{2} 1.0 \mathrm{cc} / \mathrm{kg}$ 静注, 30 分後

$\sqrt{\prime} \mathrm{Az} . \mathrm{S} 80 \mathrm{mg}$ per OS.)

\begin{tabular}{|c|c|c|c|c|c|c|c|}
\hline \multicolumn{2}{|c|}{ 家 蚛 } & \multirow{2}{*}{$\begin{array}{l}\text { 良時 } \\
\text { 中 } \\
\text { 初 } \\
\text { 発間 } \\
\text { (分) }\end{array}$} & \multicolumn{4}{|c|}{ アゾルビ S 尿中排泄量 $(r)$} & \multirow{2}{*}{ 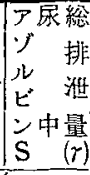 } \\
\hline 番号 & $\begin{array}{l}\text { 体重 } \\
(\mathrm{kg})\end{array}$ & & 1·時間 & 2 時間 & 3 時間 & 4 時間 & \\
\hline 56 & 2.5 & 100 & 0 & 18.8 & 24.5 & 20.8 & 64.1 \\
\hline 57 & 2.3 & 120 & 0 & 0 & 34.1 & 31.2 & 65 \\
\hline 58 & 2.1 & 100 & 0 & 3.5 & 5.9 & 10.1 & \\
\hline 59 & 2.1 & 100 & 0 & 9.8 & 20.2 & 11.0 & 41.0 \\
\hline 60 & 2.1 & 105 & 0 & 7.0 & 18.0 & 14.2 & \\
\hline \multicolumn{2}{|c|}{ 平 } & 均 & 0 & 7.8 & 20.5 & 17.5 & \\
\hline
\end{tabular}

家鬼を背位に固定し，腹部を正中線で切開して腸管 を取り出し，上腸間膜動脉，及び間脉にカニューレを 插入し，動脉儧からマリオット瓶中の体温飞温めた Tyrode 液通して, 腸間膜血管之腸壁内毛細管内之 飞残孔る血液を洗い流す。次治幽門部から下方 $5 \mathrm{~cm}$ （十二指腸上部）及び回盲部沈於いて夫久晹管を二重 結紫し，又，直接には実験とは無関係であるが実験時 間の関係上大腸へ行く晹間膜血管を分離与る䫅を除く ためと大腸下端でる二重結紮して, 腸間膜をつけたま ま十二指腸上部及び大腸下端で切除し， $38 \sim 39^{\circ} \mathrm{C}$ K 保てる Tyrode 槽内に入れて自由腸管運動の出来る 様にした。即ち, 本装置火は小腸, 大腸, 腸間膜, 及地 び腸間膜血管を含む事くなる。Tyrode 液の灌流は摘 出時乞のまをと, 上腸關膜動脉より流入, 門脉上り 流出せしめた。灌流圧は $10 \mathrm{~cm} \mathrm{H}_{2} \mathrm{O}^{16) 17718)}$ とし, 灌流

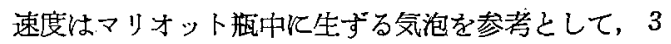
秒閵 2 気泡の速度で灌流した。Az.S は $80 \mathrm{mg}$ を $15 \mathrm{cc}$

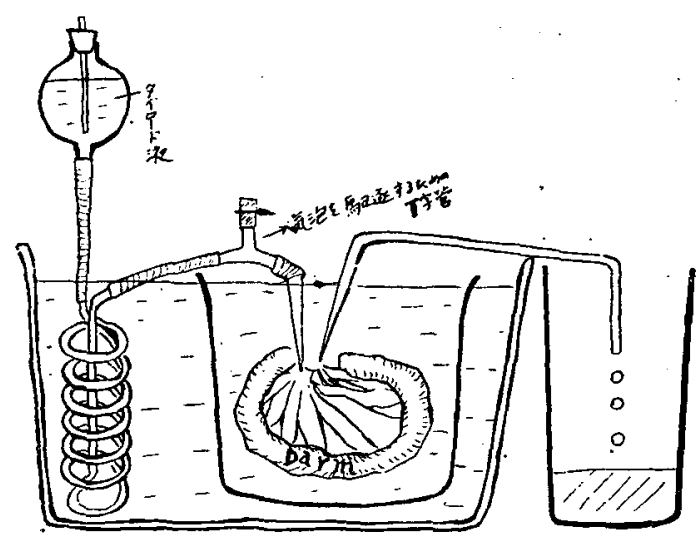

第3図腸管灌流装置

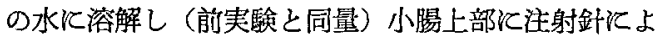
り腸壁を通して注入し，門脉より出る灌流液を 2 時間 に亘り，各々 30 分每に採取し，Az. S を定量した。

手術時間は実験成䋶に大きな影響を及ぼすので可文 的短時間飞，而す手技は正確行行亨が必要である。 又, 実験前 24 時間は絶食させた。小腸内容は殆んど 見られなかつた。

斯る実験方法に於ては，手術後 1 時間では腸管水腫 を見る事はなく，又，腸管運動も活潑に保たれている が，実験 2 時間に及べば腸壁はやや水隀状となり，又 腸管はガスのため䐍满し，且つ，腸管運動の減弱を来 す。故纪手術後 1 時間以上の成績は余り正確と以云兄 ない。依つて私は，吸收量を手術後 1 時間， 2 時間泟 区切り夫久推計学的に検討した。又, 血管灌流 2 時間 後腸管内容を蒸留水て洗條し，この洗滌液についてる Az.S を溷定した。

B. 実験成綘（第 10 表）

a) 正常例

4 例飞就いての成續は

1. 初加 1 時間吸収量は平均 $4910.2 \gamma$,

2. 何れも初めの 30 分の受収量が最も多い。

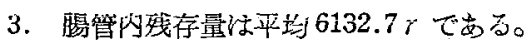

b) 肝臟障碍例

実験汅法: 肝践障碍社 $\mathrm{CCl}_{4} 0.1 \mathrm{cc} / \mathrm{kg}$ 右大腿皮下 注射により行い，注射 24 時間後飞実験を開始した。 6 例汇就いての成續は

1. 初めの 1 時間吸収量性平均 $3394.9 \gamma$,

2. 1 例を除いて何れる初めの 30 分の吸収量が最 ○多い。

3. 腸管内残存量忙平均 $9394.3 r$ である。

以上の成績を正常例飞比較すると，1時間吸収量は 正常例との間汇 $5 \%$ 危除率で有意の娍少を示し， 又，腸管内容については $5 \%$ の危険率で正常例は肝臟 障碍例より少なかつた。即ち, 肝藏障碍例は正常例保 此へて腸管吸収機能悪?，従つて腸管内残存量も多い と云う事になる。

\section{c）肝灆障䀐後塩化カルシウム苗荷例}

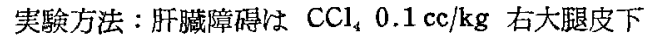
注射により行い，注射 24 時間後に $10 \%$ 塩化カルシウ $\triangle 1.0 \mathrm{cc} / \mathrm{kg}$ 静注し, 静注 30 分後に灌流を行つた。

5 例飞就いての成績は

1. 初めの 1 時間吸収量恃平均 $10485.8 r$,

2. 何れ子初めの 30 分の吸収量が最も多い。

3. 腸管内残存量忛平均 $4801.5 r$ である。 
以上の成續を正常及び肝瀻障㧹例に比較すると，1 時間吸收量は正常及び肝臓障碍例之の間々 $1 \%$ の危険 率で有意の增加を热め, 又, 腸管内残存量认正常例之 の間には有意の差なく，肝㵴障碍例との間には， $1 \%$ の危険率で有意の減少を示した。即ち, 肝瞞障码後, 肝葴機能穴進剂である塩化カルシウムを投与すると，

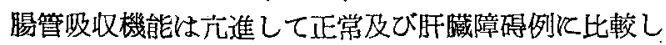
て有意の增加を示し, 従つて腸管内残存量の減少を来 した。

以上より肝蔵障碍後塩化カルシウム負荷家躳の $\mathrm{Az}$. $\mathrm{S}$ 経口投与実験で，その尿中 Az. S 排泄量の減少を 来したのは, 恐らく腸管吸収機能の改善々, 肝臟色素 排泄機能の亢進との組合せの結果であると思われる。 Az.S 排泄の型が正常例のそれ《一致しているのは是 第10表 剔出保生腸管灌流実験

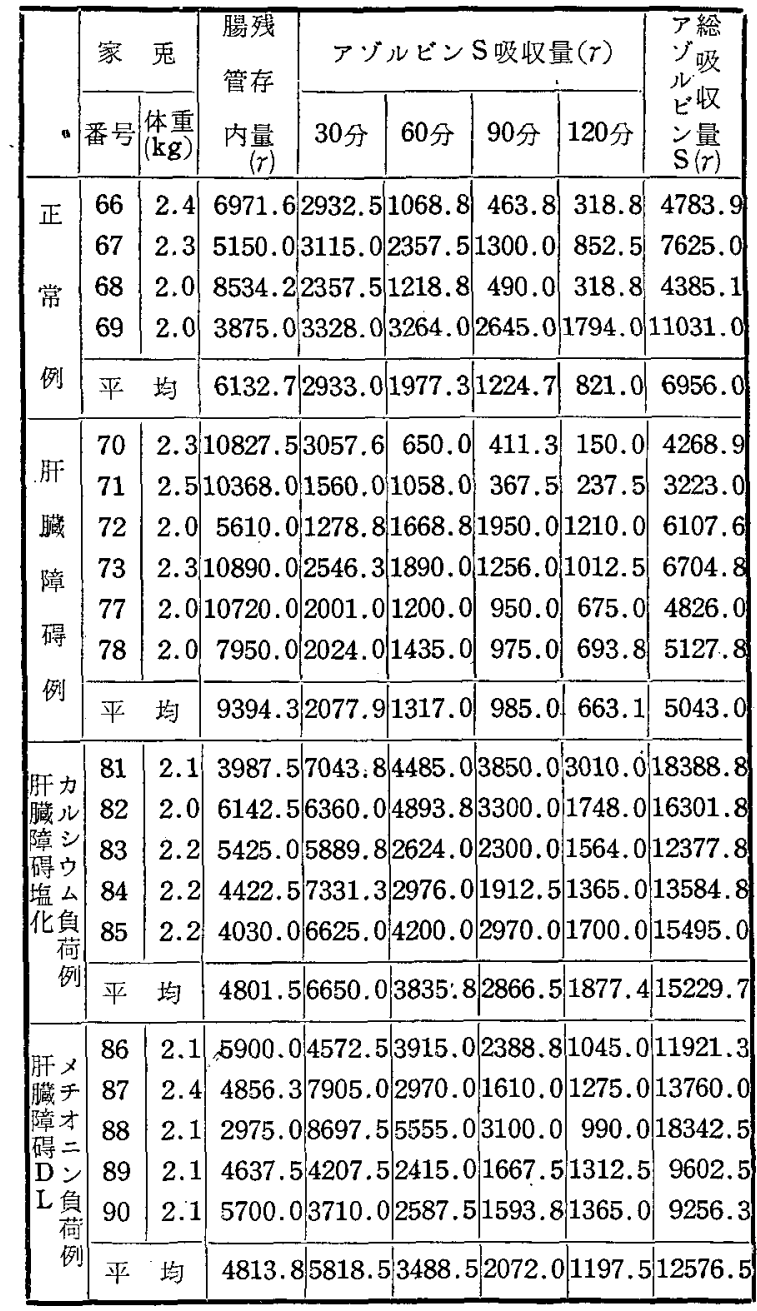

れを裹附けるるのと考えられる。

d) 肝臟障碍後 DL-Methionin 負荷例

Methionin は抗脂肪肝作用があり, 種々肝臟聅患の 治療に使われているが，私は肝䑏障碍後 Methionin を投与した場合の腸管吸収機能の変化を追究した。即 5 Methionin 投与による肺臟障㧹の改善程度と此例 して腸管吸収機能が改善されれば，両贜器の閻には正 の相関関係があると結論し得る。兹問題となるのは Methionin の直接腸管吸収機能江及ほす影響の有無 であるが Methionin は 12 時間前倩注するのるであ り, 且つ, 実験中は不断飞晹管壁血管は Tyrode 液飞 て灌流されているのであるから Methionin 単独の腸 管に対する直接の影響仿殆えどないと思われる。しか 乙全面的に是れを否定する事は出来ない。

実験方法：肝臟障碍は $\mathrm{CCl}_{4} 0.1 \mathrm{cc} / \mathrm{kg}$ 右大腿皮 下注射に上り行い，注射 12 時間後に DL-Methionin $100 \mathrm{mg}$ ( $2 \%$ 液 $5 \mathrm{cc}$ ，ミノファーゲン製薬)を 静注しその 12 時間後 (即ち, $\mathrm{CCl}_{4}$ 注射 24 洔間後) に灌流を行つた。

5 例飞就いての成繥は

1. 初めの 1 時間财収量注平均 $9307.0 \%$,

2. 何孔も初めの30 分の略収量が最子多い。

3. 晹管内残存量は平均 $4813.8 r$, である。

以上の成績を正常及び $\mathrm{CCl}_{4}$ 投与例と此較すると 1 時間吸収量は $5 \%$ の危険率で正常及び $\mathrm{CCl}_{4}$ 投与 例飞比へ有意の增加を見ている。更湯管内残存量 飞就いては, 正常例との間には有意の差なく $\mathrm{CCl}_{4}$ 投与例との間には $1 \%$ 危険率で有意の隇少を示乙 た。即ち,肝撼障硽後 DL-Methionin を投与すると 腸管财収機能は元進乙，同時江腸管内残存量の娍少 を来すと云う事が判つた。

\section{v. 総括及び考按}

用臟は物䨘代謝の面でる重要な役割を有し，肝葴 障碍が存在する時汇は是等代謝の円滑なる遇航を奶 げ, 就中, 糖, 蛋白, 脂肪の中間代謝飞悪影響を及 ぼし，解毒機能の低下と相俟つて栄養障碍を蕧起す る事が考亲られる。一方それ以前の問題として肝臓 障碍時の腸管吸収機能を追求する事は意義あるるの と思われる。

私は肝臓障㧹と腸篦吸収機能との間の関係を知ら んとして本実験を行い，それと同時に色素経口投与 そよる肝灆機能検查法が可能力否かを検討した。

本実験では成績判定の容易なる点及び消化と云う 要約を除外して主に吸収機能を検查し得る点等上り 
乙て生化学的特異性の物賈は暫く拓き，色素剂 Az. S

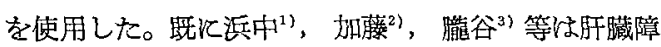
碍時には腸管财収機能の低下を来矛を報告してい

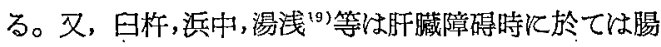
液の酸, 塩基中和能の低下，又，実験家鬼小腸伦於て 著明なる緊張の低下と運動の不規則且つ緩慢なる專夹

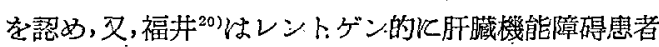
の消化管の軍動機能を検索し，小腸の緊張弱く，排泄 時間の延長を来すと云万事を明らか玑した。凡と色素 が血中に吸収されると，肝藏はとの異物排泄機能によ

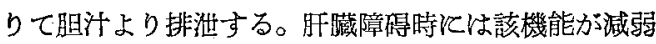
し，ために血中濃度は正常に比して高くなり，尿中排 泄量の堌加を来す事は明らかである。この点を利用し て多くの色素剂が月下䑏機能検查法飞使用されて居る。

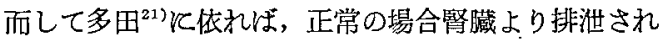
ない色素は主要排泄路たる総輸胆管が結禁された場合 です遂に腎藏より排浛される事なく，正常の場合肝臓 及び腎臟より排泄される色素の及総輸胆管結禁後に於 て代償的江腎藏より排泄されると。Az.S.は盘中机入 るとその大部分が訮藏より排泄され，尿中には僅かし か排泄され双点より肝䑏機能検查に利用されている。

以上の如く血中澚度が正常と等しい程度であるなら ば, 朋䠞障碍の場合は当然尿中排泄量の增加を来すべ き事は明らかである。肝臓機能低下時 Az.S 経口投与 の場合，その尿中排泄量の減少を来したのは，1）腸 管吸収機能の減退，2）腎葴排浛機能の变化が考えら れる。私はこの点を究明せんとして，前記成績と，晹 間膜静脉より Az. S を注入した場合の成績とを比較 した。Az.S 腸間膜静脉注入例の場合出，肝藏障碍時 飞江正常例飞比一，1)尿中色素初発時間の促進，2)尿 中色素排泄量の增加，を来し，Az.S 吸收量が等しい 場合には肝藏障碍例では正常例汇比へ尿中色素初発時 間の促進と Az. S 尿中排泄量の藷明な增加を来す事 が想像された。この事より胿噳障碍時 Az. S 経口投 与の場合尿中 $\mathrm{Az} . \mathrm{S}$ 排泄量の減少は, 以上の例が全 て尿中蛋白陰性で一応等の影響を除外乙得る点上りし て,Az.S 吸収機能の低下による事を思わせた。

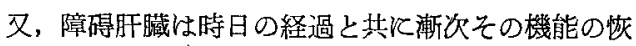
復を来す事は既に知られているが，私は斯る場合に， 腸管吸収機能が䀒臓機能の恢復飞つれて如何なる変化 を来すかを尿中 Az.S 排泄量を参考として追究したと ころ，腸管四収機能子亦肝蔵機能の改善に平行して良 くなる事が明らかとなつた。 以上の点より肝臓障碍時には腸管吸収機能の減弱を
来し, 㕛, 肝藏障碍の改善されるにつれて腸管吸収機 能も好転すると云う推諭を得ると至つた。

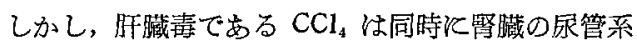
及び脉管系に変化を与兄 ${ }^{22}$, 又, 肝臓障碍は等臟の機能 的並び温織学的損傷を生ぜしめると云われ ${ }^{23)}$ ，一方， 菊地 ${ }^{24}$ ほ 肝動脉結㷊時於ては肝臟障碍の程度は大で あるが，算蔵は若下の幾能的低下を見たに過ぎず，組 織学的にる病的変化は想められないと述へている。本

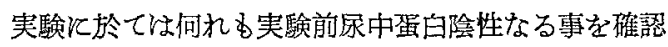
しこいるために一応腎藏自身の影響は除外し得るとは

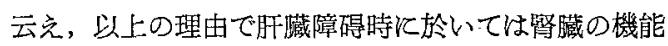
低下を見る事は十分考克られ，この理由で肝臟障碍時 飞尿中排泄量より腸管吸収機能を推測する事は最善の 方法とは荐えられない。斯る点を明らかにするため私 は更飞家鬼剔出保生腸管灌流実験を行い，肝臓障碍時 そは腸管吸収機能の低下を来すと云う事を確認する事 が出来た。

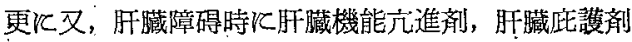
を使用した場合に，腸管吸收機能々改善されるである うかと云う事は臨床的にる極めて興味ある問.題であ る。このため私は塩化カルシウム, DL-Methionin を 使用し実娩を行つた。

カルシウムが肝臓の色素排浛機能飞対して促進的に 憉らく事は明らかであり, 既飞 Minot \& Cutler ${ }^{8)}$ 肝臟障碍の予防及び治療にカルシウム剂の有効なる事 を報し，この理由に就いては，肝践障碍時血中飞蓄積 したグアニジンに拮抗的に作用するためと述へ，重見

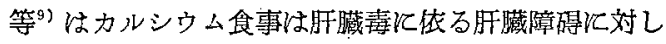
好影響を与え, 適当なるカルシウム食事は肝䁍機能化 対し一種の Reservekraftを与光々述へて居り，原 ${ }^{25}$ は重見の成績 ${ }^{26}$ 《基づき，カルシウムのグアニジン 飞対する拮抗作用の他飞, 朋臟障碍時任呈するカリウ ムの毒作用炕対するカルシウムの持抗作用化す因ると 述へて居る。一方, 大橋 ${ }^{10}$ 枆乳酸代謝の面より, 更飞 硳生田 ${ }^{11)}$ はビリルビン代謝，ウロピりン代謝の面より カルシウムの肝臟機能進作用を報じて居る。又,下

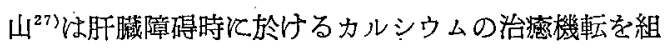
織学的に追究し, カルシウムは枵器器の治傯機転を促進 乙, 且つ, 中毒飞因る死期を崖延し得交と述へている。

Methionin ${ }^{2882930)}$ अ乞の不安定なメチル基による抗 脂肝作用の他保，含硫アうノ酸特有の細胞賦活作用， リボ核酸堌加仁依る組胞再生作用あり，又 Sulfhydryl

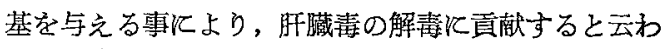

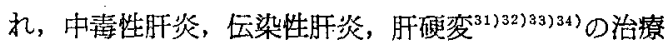


と有効であると云われ，Beams ${ }^{35)}$, Steigmann ${ }^{36}$ 等は 肝硬変飞 Methionin を投与して Needle biopsy を 行い, 臨床像の好転と肝藏病変の正常化及び病的脂肪 の消失等を見て居る。又, 井上 ${ }^{37}$ 性肝臓疶患江 LMethionin を投与して, 肝臟解毒機能, プロトロンビ

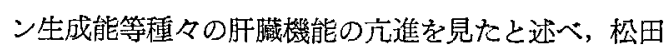
${ }^{38}$ は健康家鬼では綜合アミノ酸である Mariamin は 肝臟機能を著明に六進させるが，L-Methionin，DLMethionin では元進を認めず，一方，肝脿障碍後に 投与すると何れる胿藏機能の六進を来し, 又, 予め L-Methionin を投与して扔くと $\mathrm{CCl}_{4}$ 中毒を軽減す ると報じ, 現在 Methionin は臨㦿的㶥肝藏疾患恃勿 論，その他多方面に利用されている。

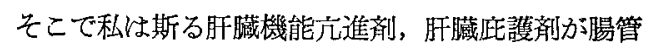
吸収に対して如何なる態度を取るか老家鬼剔出保生腸 管灌流実験, 生体実験飞上り検索し, 肝臓機能の腸管 吸収機能に対寸る関係を追究したが，肝臓機能元進 剤, 肝藏应護剂投与例々肝藏障碍例飞比乙何れ子腸管 吸收機能が元進している。

剔出保生晹管灌流実験汸いて問題となるのは塩化 カルシウム及び DL-Methionin の晹管吸収機能に直 接及ばす影響であるが,斯る薬剂は何れる実験前 30 分 及び 12 時間飞静注するのみであり，且つ，腸管は不 断灌流液炕て灌流されているのであるからとの影響 は殆んどないと思われるが，この実験からは全く影響 を及煌さないとは断言出来ない。

乙か乙，肝臟障碍後に㙁化カルシウム或いは DL-Methionin を投与した例では，Az. S 吸収量が肝臓障 碍例は勿論, 正常例よりる増加した事は興味深い事と 思われる。

以上を総括して私は, 肝臟政碍時には晹管吸収機能 は減弱する。斯る腸管吸収機能減弱も肝臓機能の正常

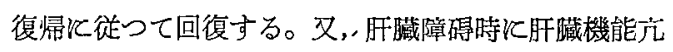
進剂, 肝臓庇護剂を投与する時は腸管吸収機能は九進 すると云う結論を得ると至つた。

又, 以上の事実より考按して肝臟障碍時汇於ける斯

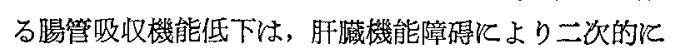
招来されたすのであると考えられる。

最後江本研究の目的の一つであるところの，Az. S 释口投与による肝臟機能検查が可能か, 否かの問題で ある。

元来, 本色素による肝臓機能の検査は, これを静脉 内注射し, その胆汁中渄泄される量の多少, 遅速 等てより肝臓機能を判断したるのである。胆㳡中の色
素排泄を観察することの媔わしさの代りに尿中排泄色 素を以てしたのが今日の一般使用される尿中排泄に上 る検查法である。

即ち，胆汁中に排泄される量が減少すればそれに反 此例して㽷中色素が增加すると云う考え方によるもの である。

Az. S を経口的飞投与する場合, 若し消化器系統か らの吸収が肝臓機能の如何俰らず同一であるなら ぼ，旰贜機能の検查方法中色素の静注の代りに経口投 与を採用してる何等差し支えないわけであるが，本研 究の結果によれば肚臓障碍時には腸管よりの吸収が障 碍される事は明らかであるから，乙かく簡単には理ば， ない。

今, 本研究の成績を仔細に観察すると, 色素の経口 投与の場合, 肝臟機能攺淂碍がれば尿中排泄色素は 減少する結果となつている。

Az. S 静注の場合, 一般的飞は尿中色素量の減少の. 原因としては, 督藏障碍, 肝藏機能六進が考劣られ る。Az.S 経口投与で腸管の吸収障碍がこれに加わ る。腎臟《障碍方る場合は Az. S 静注《よる場合も

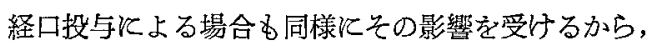
腎臓は一応問題外として考党る專にする。

Az. S 静注の場合, 尿中色素の增加は肝藏機能呧下 を示し，Az. S 経曰投与の場合は，尿中色素の增加は 晹管吸収機能良好か或い肝臟機能低下かを示す。

しかし，本研究によれば肝藏機能低下があれば腸管 吸収も従つて悪くなるから，腸管吸収良好と肝臓機能 低下と蕾立し得ない。

故に Az. S 経口投与で尿中色素の堌加は肝臓機能 の亢進を示す。只, 肝臓機能汇著変なく, 陽管吸収障 碍がある場合，尿中色素の堌加恀腸管吸収の良好を示 すのみであつて，朋臟機能については何等の事を示さ ない。しかし，肝臟㙨能の障碍がめれば腸管吸収も悪 くなる筈であるから，此の場合の尿中色素の增加は少 くとも肝臓機能の悪化を示するのではない。

以上を要約すれば，Az. S 経口投与の場合，色素の 尿中排泄が標準若しくはそれ以上の場合は肝臓機能に 障碍なしと考えてょく，排泄が標準以下であるならば 旰臓機能と腸管吸収機能とが共に低下しているか双は 後者のみ低下しているかである。

依つて本法は肝臓機能検查法の一つ或いは方補助 として使用し得ると考えられる。但し，本検查法は空 腹時に行う事が朋要である。
VI. 結
語 
$-60-(756)$

I 燐タンダステン酸を用いて尿色素の脱色を行 い，光電比色計による氺中 Az. S O微量定量法を考 案した。

II Az: S を使用して肝蔵障碍時に於ける腸管吸収 機能を家鬼生体実験, 家兄剔出保生腸管灌流実験飞就 いて検索し次の結果委得た。

i) Az.S 経口投与実験飞使用する Az. S 量は $80 \mathrm{mg}$ が適当である。即ち，この事実験に使用する Az. S 量に性動物の種類により Optimal の量がある筈であ ると云う事を示す。

ii）朋臟障碍時に於いては幐管吸収機能の減弱を 来す。

iii）肝臟障碍時に肝藏機能忍進剤である塩化カルシ ウム，肝臓庇護剤である DL-Methionin を投与する と腸管吸収機能の元進を示す。

iv）肝臓障碍時に於ける腸管吸収機能低下は，肝臟 障碍により二次的に招来されたるのである。

V) Az. S を経口投与し，その㽷中排泄の模様を観 察すること飞より肝藏機能の检查方或る程度可能です ๖。

（本論文の要旨は日本薬理学会第13回関東部会に於て 笔表した。)

\section{文献}

1) 浜中 正一：実験消化器病学，9，1500（昭9)

2) 加藤 静忍：京都府立医科大学杂隹誌，31，1135 (昭16)

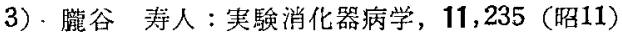

4) Conn, H.J. : Biological Stains, Biotech Pu blications, Geneva, N.Y. U.S.A. (1953)

5) 斎藤 正行：光電比色計による臨休化学検査， 南山堂, 東京 (昭28)

6)稗田憲太郎：南满医学会雑誌，12,157 (大13)

7)，中井 文二：実験消化器病学，9,1376 (昭 9)

8) Minot \& Cutler : Journ. Clin. Invest., 6,
369 (1928)

9) 重見速雄他：実験消化器病学，7,731 (昫 7)

10) 大橋 員惠：上飞同し，9，9(昭 9)

11) 称生田好婎：上沉同し，8，823(昭 8)

12) 藤井的：日医大棓，19，284（炤27）

13）松井 文英：日医大誌，20，524（昭28）

14）井田 憲明：ピタミン, 2,13(昭24)

15)，寺岡宏：生化学，25，402（昭29)

16) 塩谷 信男：朝鮮医学会雑誌, 80, 57 (昭 2)

17) 太田 敬三：児科雑誌，380,103（昭 7)

18) 奥藤 重二：京都医学会雑誌，21,1815 (大13)

19) 臼杆天成他：実験消化器病学，8，572(昭 8)

20）福井 . 潤：上K同し，11，813（昭11）

21）多田·嘉徳：日本微生物学会雑誌，17, 1005 (大12)

22) 若林 英次: 実験消化器病学, 3，371 (昭 3)

23) 水田 信夫：日本内科学会雑誌，21,129(昭 8)

24）菊地金男他：日本消化機病学会雑誌，51，145 (昭29)

25) 原亨：日本内科学会雑誌,21,205(昭 8)

26) 重見 速雄 : 䒠験消化器病学, 9, 317 (昭 9)

27）下山 政人：医海時報，2341，1529,2342,1575, 2343, 1629, 2344,1688 (昭14)

28）瀨戸桂太郎：治潦，37,11，(昭30）

29) Popper, H.et a1 : Am. Journ. Med. Sciences., 215, 624 (1948)

30) Brunschwig, A et al : Arch. Path., 40, 81 (1945)

31) Eddy, J.H. : Am: Journ. Med. Sciences., 210, 374 (1945)

32) Sahyun, M. : Am. Journ. Digest. Dis., 16, 243 (1949)

33) Cayer, D. : Arch. Int. Med., 80, 644 (1947)

34) Morrison, L.M. : J.A.M.A., 134, 673 (1947)

35) Beams, A.J. et al : Gastroenterol., 9, 718 (1947)

36) Steigmann, F.: J.A.M.A., 137, 239 (1948)

37) 井上便他：最新医学， 7,-251（昭27)

38）松田 武夫：医療，6，492（昭27） 